\title{
Identification of areas of very high biodiversity value to achieve the EU Biodiversity Strategy for 2030 key commitments
}

\author{
Iulia V Miu ${ }^{1}$, Laurentiu Rozylowicz ${ }^{\text {Corresp., } 1,2}$, Viorel D Popescu ${ }^{1,3}{ }^{,}$Paulina Anastasiu ${ }^{4}$ \\ ${ }^{1}$ Center for Environmental Research, University of Bucharest, Bucharest, Romania \\ 2 Chelonia Romania, Bucharest, Romania \\ 3 Department of Biological Sciences, Ohio University, Athens, Ohio, United States \\ 4 Dimitrie Brândză Botanical Garden, University of Bucharest, Bucharest, Romania \\ Corresponding Author: Laurentiu Rozylowicz \\ Email address: laurentiu.rozylowicz@g.unibuc.ro
}

\section{Background}

The European Union strives to increase protected areas of the EU terrestrial surface to $30 \%$ by year 2030, of which one third should be strictly protected. Designation of the Natura 2000 network, the backbone of nature protection in the EU, was mostly an expert-opinion process with little systematic conservation planning. The designation of the Natura 2000 network in Romania followed the same nonsystematic approach, resulting in a suboptimal representation of invertebrates and plants. To help identify areas with very high biodiversity without repeating past planning missteps, we present a reproducible example of spatial prioritization using Romania's current terrestrial Natura 2000 network and coarse-scale terrestrial species occurrence.

\section{Methods}

We used 371 terrestrial Natura 2000 Sites of Community Importance (Natura $2000 \mathrm{SCl}$ ), designated to protect 164 terrestrial species listed under Annex II of Habitats Directive in Romania in our spatial prioritization analyses (marine Natura 2000 sites and species were excluded). Species occurrences in terrestrial Natura 2000 sites were aggregated at a Universal Traverse Mercator spatial resolution of 1 $\mathrm{km}^{2}$. To identify priority terrestrial Natura 2000 sites for species conservation, and to explore if the Romanian Natura 2000 network sufficiently represents species included in Annex II of Habitats Directive, we used Zonation v4, a decision support software tool for spatial conservation planning. We carried out the analyses nationwide (all Natura 2000 sites) as well as separately for each biogeographic region (i.e., Alpine, Continental, Pannonian, Steppic and Black Sea).

\section{Results}

The results of spatial prioritization of terrestrial Natura 2000 vary greatly by planning scenario. The performance of national-level planning of top priorities is minimal. On average, when 33\% of the landscape of Natura 2000 sites is protected, only $20 \%$ of the distribution of species listed in Annex II of Habitats Directive are protected. As a consequence, the representation of species by priority terrestrial Natura 2000 sites is lessened when compared to the initial set of species. When planning by taxonomic group, the top-priority areas include only $10 \%$ of invertebrate distribution in Natura 2000 . When selecting top-priority areas by biogeographical region, there are significantly fewer gap species than in the national 
level and by taxa scenarios; thusly, the scenario outperforms the national-level prioritization. The designation of strictly protected areas as required by the EU Biodiversity Strategy for 2030 should be followed by setting clear objectives, including a good representation of species and habitats at the biogeographical region level. 
1 Identification of areas of very high biodiversity value 2 to achieve the EU Biodiversity Strategy for 2030 key 3 commitments

4

5 Iulia V. Miu ${ }^{1}$, Laurentiu Rozylowicz ${ }^{1,2}$, Viorel D. Popescu ${ }^{1,3}$, Paulina Anastasiu ${ }^{4}$

6

$7 \quad{ }^{1}$ Center for Environmental Research, University of Bucharest, Bucharest, Romania

$8{ }^{2}$ Chelonia Romania, Bucharest, Romania

$9{ }^{3}$ Department of Biological Sciences, Ohio University, Athens, Ohio, United States of America

$10{ }^{4}$ Dimitrie Brândză Botanical Garden, University of Bucharest, Bucharest, Romania

11

12 Corresponding Author:

13 Laurentiu Rozylowicz ${ }^{1}$

141 N. Balcescu, Bucharest, 010041, Romania

15 Email address: laurentiu.rozylowicz@g.unibuc.ro 
18 Abstract

19 Background

20 The European Union strives to increase protected areas of the EU terrestrial surface to $30 \%$ by

21 year 2030, of which one third should be strictly protected. Designation of the Natura 2000 network, the backbone of nature protection in the EU, was mostly an expert-opinion process with little systematic conservation planning. The designation of the Natura 2000 network in Romania followed the same non-systematic approach, resulting in a suboptimal representation of invertebrates and plants. To help identify areas with very high biodiversity without repeating past planning missteps, we present a reproducible example of spatial prioritization using Romania's current terrestrial Natura 2000 network and coarse-scale terrestrial species occurrence.

\section{Methods}

We used 371 terrestrial Natura 2000 Sites of Community Importance (Natura 2000 SCI), designated to protect 164 terrestrial species listed under Annex II of Habitats Directive in Romania in our spatial prioritization analyses (marine Natura 2000 sites and species were excluded). Species occurrences in terrestrial Natura 2000 sites were aggregated at a Universal Traverse Mercator spatial resolution of $1 \mathrm{~km}^{2}$. To identify priority terrestrial Natura 2000 sites for species conservation, and to explore if the Romanian Natura 2000 network sufficiently represents species included in Annex II of Habitats Directive, we used Zonation v4, a decision support software tool for spatial conservation planning. We carried out the analyses nationwide (all Natura 2000 sites) as well as separately for each biogeographic region (i.e., Alpine, Continental, Pannonian, Steppic and Black Sea).

\section{Results}

The results of spatial prioritization of terrestrial Natura 2000 vary greatly by planning scenario. The performance of national-level planning of top priorities is minimal. On average, when $33 \%$ of the landscape of Natura 2000 sites is protected, only $20 \%$ of the distribution of species listed in Annex II of Habitats Directive are protected. As a consequence, the representation of species by priority terrestrial Natura 2000 sites is lessened when compared to the initial set of species. When planning by taxonomic group, the top-priority areas include only $10 \%$ of invertebrate distribution in Natura 2000. When selecting top-priority areas by biogeographical region, there are significantly fewer gap species than in the national level and by taxa scenarios; thusly, the scenario outperforms the national-level prioritization. The designation of strictly protected areas 
49

50

51

52

53

54

55

56

57

58

59

60

61

62

63

64

65

66

67

68

69

70

71

72

73

74

as required by the EU Biodiversity Strategy for 2030 should be followed by setting clear objectives, including a good representation of species and habitats at the biogeographical region level.

(1)

\section{Introduction}

Protected areas, a critical tool for nature conservation strategies, are intended to ensure the longterm persistence and viability of biodiversity. These areas should support many rare, threatened, or endemic taxa, particularly those with low mobility and high sensitivity to environmental alterations as possible (Geldmann et al. 2013; Gray et al. 2016; Possingham et al. 2006; Rodrigues et al. 2004). When planning protected areas, states around the world are guided by supranational policies such as Convention on Biological Diversity and EU Biodiversity Strategy for 2030, which issue ambitious objectives to increase the extent of protected areas. For example, Convention on Biological Diversity (CDB) Aichi Target on Protected Areas calls for the protection of $17 \%$ of the world's terrestrial and inland water areas in key regions for biodiversity and ecosystem services (UNEP 2011), while the EU Member States seek to increase by 2030 the Natura 2000 network to $30 \%$ of which one third should be under strict protection as areas of very high biodiversity and climate value (European Commission 2020).

A promising tool to help build an ecologically-sound network of protected areas meeting the CDB or EU targets is systematic conservation planning (Margules \& Pressey 2000). Systematic conservation planning maximizes conservation benefits while minimizing impacts on other resources, such as the availability of productive land. Spatial conservation prioritization, as a part of systematic conservation planning, customarily relies on the complementarity concept (i.e., selection of complementary areas to avoid duplication of conservation effort) and is considered an efficient instrument for identifying spatial priorities and achieving conservation goals (Margules \& Pressey 2000; Pressey et al. 2007).

One of the most extensive networks of conservation areas in the world is the Natura 2000 network, which has been created to operationalize EU Birds (Directive 2009/147/EC) and Habitats Directives (Council Directive 92/43/EEC). To date, Natura 2000 encompasses 18\% of EU terrestrial area, thus meeting the CDB Aichi Target on Protected Areas (UNEP 2011). The effectiveness and representativity of Natura 2000 were evaluated for different taxonomic groups 
and geographic areas, and the conclusions tended to highlight suboptimal planning (D'Amen et al. 2013; Dimitrakopoulos et al. 2004; Kukkala et al. 2016; Lisón et al. 2013; Müller et al. 2018; Müller et al. 2020; Votsi et al. 2016). The suboptimal planning of Natura 2000 at the EU and at Member States levels originates from an uncoordinated process (Apostolopoulou \& Pantis 2009; Iojă et al. 2010; Lisón et al. 2017; Orlikowska et al. 2016), which was partially resolved by selecting new sites after expert-opinion evaluations during the Natura 2000 biogeographical seminars (Kenig-Witkowska 2017; Manolache et al. 2017). Furthermore, the efficacy of the Natura 2000 network was extensively re-evaluated from other perspectives, for example, for understanding the effect of climate change on representativity (Araújo et al. 2011; Popescu et al. 2013) and for coordinating conservation investments (Hermoso et al. 2017; Nita et al. 2016).

The designation of the Natura 2000 network in Romania followed the same non-systematic approach. The process started in 2007 with designating 273 Sites of Community Importance covering Habitats Directive. This process continues in the present; nowadays, there are 606 designated Natura 2000 sites (Sites of Community Importance and Special Protection Areas) that encompass $23 \%$ of the total country's land area $\left(54214 \mathrm{~km}^{2}\right)$ (DG Environment 2020; Manolache et al. 2017). Of these, 426 are terrestrial Natura 2000 Sites of Community Importance, covering $40310 \mathrm{~km}^{2}$ (17\% of Romania's terrestrial surface) (DG Environment 2020; EIONET 2020). During the first two designation stages, the process was highly biased towards overlapping existing national protected areas (Iojă et al. 2010; Manolache et al. 2017), and thus, even if the CBD 17\% target is met, the effectiveness of Natura 2000 in representing habitats and species is questionable. For example, Iojă et al. (2010) confirmed that overlapping existing national protected areas resulted in a suboptimal representation of plants and invertebrates; Miu et al. (2018) highlighted underrepresentation of agricultural landscape in Dobrogea, while Mânzu et al. (2013) and Popescu et al. (2013) concluded that the Natura 2000 network would not protect plants, reptiles, or amphibians if species ranges shift under climate change scenarios.

With the latest extensions, the Romanian Natura 2000 network encompasses all species and habitats listed in Habitats and Birds Directives (DG Environment 2020; Manolache et al. 2017); however, the new EU Biodiversity Strategy for 2030 requires an increase from $23 \%$ to $30 \%$ of the total terrestrial country's area of which one third should be under strict protection as areas of very high biodiversity and climate value (European Commission 2020). To help identify areas with very high biodiversity and to provide an example of systematic planning of a protected area 
110 network, we present a reproducible spatial prioritization case study using Romania's current

111 terrestrial Natura 2000 network and coarse-scale terrestrial species occurrence (marine Natura

1122000 sites and species were excluded). The objectives of this study are (1) to identify candidate

113 sites for designation as areas of very high biodiversity within the Romanian terrestrial Natura

1142000 network in national, taxa-specific and biogeographical levels spatial prioritization scenarios

115 and (2) to investigate the extent to which the areas of very high biodiversity within terrestrial

116 Natura 2000 network cover the species listed in Annex II of Habitats Directive in national, taxa-

117 specific and biogeographical levels spatial prioritization scenarios. The European Union assesses

118 the effectiveness of Natura 2000 network in protecting species and habitats listed in Birds and

119 Habitats Directives at the Member State level but also at the biogeographic level (Evans 2012);

120 thus, we performed the analyses at both administrative levels.

121

122

123

124

125

126

127

128

129

130

131

132

133

134

135

136

137

138

\section{Methods}

\section{Natura 2000 sites and species}

The dataset used in our planning analysis included 371 terrestrial Natura 2000 Sites of Community Importance (Natura 2000 SCI), designated to protect 164 terrestrial species listed under Annex II of Habitats Directive in Romania. The initial database included 426 Natura 2000 SCI and 166 species (EIONET 2020), from which we excluded 7 sites with a small area $\left(<1 \mathrm{~km}^{2}\right.$, the spatial resolution of our data), 48 terrestrial sites designed only for habitat protection, and 2 marine species (the common bottlenose dolphin - Tursiops truncatus, and the harbor porpoise Phoecena phoecena) (Data S1). We used only terrestrial sites and species to match the EU commitment to designate by 2030 as strictly protected of one-third of protected areas separately on land and at sea (DG Environment 2020). Of the 164 species protected by this terrestrial Natura 2000 network, 26 are mammals, 6 are reptiles, 6 are amphibians, 26 are fish, 54 are invertebrates, and 46 are plants. The number of species protected within a Natura 2000 site varies between 1 (46 sites protect only one species) and 62 (Iron Gates). The terrestrial sites with the largest number of protected species ( $>40$ species) are Iron Gates, Domogled - Valea Cernei, Calimani - Gurghiu, Danube Delta, Cheile Nerei - Beusnita, Fagaras Mountains, and Tur River. The largest Natura 2000 sites in terms of surface area $\left(>1200 \mathrm{~km}^{2}\right)$ are Danube Delta, Fagaras Mountains, Frumoasa, Calimani - Gurghiu, and Iron Gates (Rozylowicz et al. 2019). 
139 To map species occurrences in terrestrial Natura 2000, we used site-level occurrence data 140 included in the Natura 2000 Standard Data Forms (EIONET 2020). Site-level occurrence records 141 were aggregated at a Universal Traverse Mercator spatial resolution of $1 \mathrm{~km}^{2}(\mathrm{UTM} 1 \times 1 \mathrm{~km})$. 142 Thus, if a species was included in the Standard Data Form (recorded for the respective Natura 1432000 site), each cell of that site was considered as having that species present. We followed this 144 approach due to the absence of finer scale species distribution data in Romania for Natura 2000 145 taxa, which makes species distribution modelling impractical for all Natura 2000 taxa. While the 146 coarse spatial resolution likely overestimates the distribution of several range-restricted taxa, 147 data at protected area level, rather than within protected areas, is currently used for official 148 biogeographical assessments of conservation status of species and habitats in Romania under 149 Article 17 of the Habitats Directive (EIONET 2020). The likely outcome of overestimating the 150 distribution of some species for this prioritization study, which focuses on species-rich areas 151 (Additive Benefit Function algorithm, see section Priority ranking of terrestrial Natura 2000 152 sites), is that some protected areas may emerge as top priorities despite the fact that some species 153 are occurring only within a relatively small area within those respective protected areas. Thus, 154 the prioritization results should be interpreted as a Natura 2000 site with a certain proportion to 155 be designated as strictly protected areas and not as the exact position of top priority grid cells. As 156 such, this approach closely matches the approach to conservation planning in Romania, which 157 uses species lists to establish protected areas of various sizes and acknowledges that species may 158 only occur in discrete units within a given protected area (EIONET 2020).

159 The Natura 2000 sites and species considered here were further sorted by biogeographic region. 160 Because Romania lies at the geographic center of Europe (Rey et al. 2007), Natura 2000 network 161 overlaps five terrestrial biogeographical regions, out of the nine regions recognized by the 162 European Union, i.e., Alpine, Continental, Pannonian, Steppic and Black Sea (Rozylowicz et al. 163 2019). Due to its small size, the terrestrial part of Black Sea region was merged with the Steppic 164 biogeographic region (Steppic and Black Sea region in our analysis). Of the 164 terrestrial 165 species, 110 are found in the Alpine Biogeographic Region, 143 in the Continental 166 Biogeographic Region, 76 in the Pannonian Biogeographic Region, and 78 in the Steppic and 167 Black Sea Biogeographic Region. Several species were found in 2 or 3 biogeographic regions 168 due to their wide geographic range (e.g., Bombina bombina, Bombina variegata, Emys 169 orbicularis) or because they inhabit a greater range of habitats (e.g., Lutra lutra) (Data S1). 


\section{Priority ranking of terrestrial Natura 2000 sites}

171 To identify priority terrestrial Natura 2000 sites for species conservation and to explore these 172 areas adequately representing species included in Annex II of Habitats Directive, we used 173 Zonation v4, a decision-support software tool for spatial conservation planning with Natura 2000 174 sites as planning units (Lehtomäki \& Moilanen 2013; Moilanen 2007). We analyzed three 175 priority ranking scenarios: (1) nationwide, (2) nationwide for several taxonomic groups 176 separately (amphibians, reptiles, mammals, fish, invertebrates and plants), and (3) separately for 177 each biogeographic region across all taxonomic groups (Alpine, Continental, Pannonian, Steppic 178 and the Black Sea biogeographic regions) (Fig. 1). Zonation produces a priority ranking by 179 iteratively removing planning units (Natura 2000 sites in our case) with the lowest total marginal 180 loss of conservation value while accounting for total and remaining distributions of protected 181 species (Moilanen et al. 2014). Priority ranking starts from the full Natura 2000 network, and the planning units are iteratively removed until there are none remaining. Least valuable sites (e.g., low species richness) are removed first, while the valuable sites (e.g., high species richness) are kept until the end (Di Minin et al. 2014).

185

186

Zonation provides four cell removal rules (Core-area Zonation, Additive benefit function, Target-based planning and Generalized benefit function). For our case study, we used additive benefit function with exponent $z=0.25$ (the default value for species sensitivity to habitat loss), a cell removal rule with a summation structure (Moilanen et al. 2014; Moilanen 2007; Moilanen et al. 2005), which gives higher priority to planning units with a higher number of species present and tended to remove biodiversity-poor cells even if they include rare species. Thus, planning with additive benefit function may result in a selection of top priority areas that have higher performance on average, but retains a lower minimum proportion of original distributions for rare species (Arponen et al. 2005; Moilanen et al. 2014). The additive benefit function fits well to our prioritization objective - identification of high biodiversity value protected areas within the Romanian terrestrial Natura 2000 network.

The outputs of the priority analyses provide the ranking of grid cells within Natura 2000 sites according to their contribution in covering protected species $(0=$ cells with the lowest priority; 1 = cells with the highest priority). The ranking scores exhibit a uniform distribution; thus, the top spatial conservation priorities (e.g., top 33\% of the Natura 2000 network) have a Zonation 
200 ranking of $\geq 0.67$. The ranking maps are paired with the performance curves that describe the

201 extent to which each species is retained in any given high-priority or low-priority fraction of the

202 Natura 2000 network (Moilanen et al. 2005; Moilanen et al. 2011). Because we used Natura

2032000 as a planning unit layer, our analysis can be used to infer how much of a Natura 2000 site

204 should be designated as strictly protected in order to reach one third objective at network level.

\section{Results}

206 Prioritization of Natura 2000 sites at the national level

207 Terrestrial Natura 2000 sites represented as $1 \times 1 \mathrm{~km}$ grid cells cover 48954 cells $(20.24 \%$ of

208 Romanian territory), of which 4920 overlaps less than 5\% with the respective protected area. The

209 Natura 2000 sites with high priority grid cells extend over the Carpathians and Transylvania

210 (Fig. 2). Outside of Carpathians (Eastern and Southern Romania), the top-priority Natura 2000

211 sites were principally located along river corridors. The sites with the largest number of grid cells

212 labeled as priority for conservation $\left(>400 \mathrm{~km}^{2}\right)$ are Sighisoara Tarnava Mare, Muntii Ciucului,

213 Trascau, Valea Izei si Dealul Solovan, Muntele Ses, Retezat, Podisul Lipovei Poiana Rusca,

214 Dealurile Tarnavei Mici Biches, Semenic Cheile Carasului. A notable exception is the Natura

2152000 overlapping the lower course of Ialomita river in Eastern Romania (Fig. 2, Data S2).

216 Top-priority sites in national level scenario cover $37 \%$ of Natura 2000 protected grid cells in 217 Alpine biogeographic region, 28\% of protected grid cells in Continental biogeographic region,

$21822 \%$ in Pannonian biogeographic region, and 12\% Natura 2000 protected grid cells in the

219 Steppic and the Black Sea biogeographic region (Fig. 2, Data S2).

220 The performance of national-level planning of top priorities is minimal. On average, when $33 \%$ 221 of landscape of Natura 2000 sites is protected, only $20 \%$ of distribution of species listed in 222 Annex II of Habitats Directive are protected (Fig. S1). As a consequence, the representation of 223 species by priority terrestrial Natura 2000 sites is lessened when compared to the initial set of 224 species, with 20 species (12\%) not covered by the top 33\% of protected grid cells. The missed 225 species include plants (12 species), invertebrates (4 species), fish (2 species) and mammals (2 226 species) (Table 1, Data S3).

\section{Prioritization of Natura 2000 sites at national level by taxonomic group}


228 When priority ranking maps are organized by taxonomic group, the top-priority sites are

229 dissimilar to the results of national level prioritization (Fig. 3). For amphibians, the ranking map

230 (Fig. 3B) indicates that sites with high priority grid cells for conservation are spatially grouped in

231 the western and central parts of Romania, while for reptiles, the sites were clustered in the

232 southwestern and southeastern part of Romania (Fig. 3B). For mammals and plants, most of the

233 high-priority sites are spatially grouped in the Carpathians and Dobrogea areas, regions with

234 large protected areas and high species richness. High priority Natura 2000 sites for invertebrates

235 and fish are dispersed within the country (Fig. 3C-F).

236 The performance of top-priority Natura 2000 sites in representing species distribution varies by

237 taxonomic group (Fig. S2). For invertebrates, the prioritization ranking indicates that if the top

$23833 \%$ of the landscape included in Natura 2000 sites is strictly protected, on average only $20 \%$ of

239 the invertebrate distributions in Natura 2000 are also protected; this is followed by the amphibian

240 group, with over $50 \%$ of the amphibian distribution in Natura 2000 protected. For reptiles,

241 Natura 2000 performs better, with over $90 \%$ of the distribution of reptiles in strictly protected

242 areas. For mammals, fish, and plants, the Romanian Natura 2000 network performs very well,

243 with more than $75 \%$ of distribution of the respective species strictly protected when the

244 identified top priority $33 \%$ of Natura 2000 area is protected.

245 Prioritization of Natura 2000 sites at biogeographical level

246 Within the Alpine biogeographic region, the high-priority areas are in Western Carpathians

247 (Natura 2000 sites overlapping Trascau and Apuseni Mountains), Southern Carpathians (Natura

2482000 sites overlapping Retezat, Domogled, Cerna, Cozia Mountains), and Eastern Carpathians

249 (Natura 2000 sites overlapping Maramures and Gurghiu Mountains) (Fig. 4A, Data S2). Within

250 the Continental biogeographic region, the main high-priority areas overlap Natura 2000 sites in

251 Iron Gates, Semenic, Cheile Nerei (SW Romania), Sighisoara Tarnava Mare (center of

252 Romania), Dealurile Clujului de Est (center of Romania), Tur River (northwest of Romania), and

253 Ciuperceni - Desa (south) (Fig. 4B, Data S2). In the Pannonian biogeographic region, the main

254 high-priority area is in the Lower Mures Floodplain and Carei Plain (western part of Romania)

255 (Fig. 4C, Data S2). In the Steppic and terrestrial Black Sea biogeographic regions, the high-

256 priority areas are North-Dobrogea Tableland, Macin Mountains, Canaralele Dunarii, and Padurea

257 si Valea Canaraua Fetii - Iortmac and Lower Siret Floodplain Natura 2000 (Fig. 4D, Data S2). 
258 The performance of Natura 2000 by biogeographical region is similar for Alpine, Steppic-

259 Terrestrial Black Sea and Pannonian. In these regions, when the top 33\% of the respective region

260 is strictly protected, between $55 \%$ and $65 \%$ of the distribution of covered species is strictly

261 protected. The Continental biogeographic region performs better when considering that $33 \%$ of

262 landscape of Natura 2000 sites are strictly protected; nearly $75 \%$ of the distribution of species

263 listed in Annex II of HD are strictly protected (Fig. S3).

264 The biogeographic level planning scenario produced fewer gap species (i.e., not covered within

265 the strictly protected area network) than the national level scenario when selecting top priorities

266 (Fig. 5, Data S3). Out of 118 species included in Alpine biogeographic region, 9 are gap species

267 if planning is done at the national level and 3 if planning is done at the biogeographical level. Of

268149 species in Continental biogeographic region, 37 are gap species when prioritization is done

269 at the national level and 6 when it is done at the biogeographical level. Furthermore, out of 75

270 species represented in Pannonian biogeographic region, 27 are gap species in national-level

271 scenarios and only 3 in biogeographical level scenarios. Also, the number of gap species is

272 reduced when planning is done at the Steppic and Black Sea biogeographic region level, with no

273 gap species out of 38 in national-level scenarios and only 12 species in biogeographical level

274 scenarios.

\section{Discussion}

276 The EU Biodiversity Strategy for 2030 acknowledges that the current network of protected areas, 277 including those under strict protection, is not sufficiently large to safeguard Europe's biodiversity

278 in the face of multiple stressors. To overcome this issue, the European Commission set ambitious

279 conservation objectives for Member States, such as the enlargement of protected areas to at least

$28030 \%$ of terrestrial national territory in Europe, of which one-third should be strictly protected

281 (European Commission 2020). To support policymakers in establishing criteria and guidance for

282 meeting the objective of one-third of protected areas under strict protection, we tested three

283 spatial conservation prioritization scenarios using the Romanian terrestrial Natura 2000 network

284 as a case study. Our analyses suggest that selecting strictly protected areas at the European

285 Biogeographical Region level performs better than nationwide or taxa-specific planning

286 scenarios in terms of species representation and spatial evenness of selected sites. 
287 The EU Biodiversity Strategy for 2030 outlines key principles designation of areas of very high

288 biodiversity value, such as including carbon-rich ecosystems (old-growth forests, peatlands) or 289 outermost regions. The strategy also stipulates potential planning scenarios, e.g., at EU bio290 geographical regions, national level (European Commission 2020). Because the backbone of 291 strictly protected areas will be within the Natura 2000 network, which already covers over $17 \%$ 292 of EU land, these areas with high biodiversity value should also ensure the long-term survival of 293 species and habitats listed in Birds and Habitats Directives (Evans 2012), therefore contributing 294 to the implementation of the two Directives by the EU Member States.

295 In the case of Romanian terrestrial protected areas, when spatial conservation prioritization is 296 done at the national level, the top 33\% protected grid cells cover, on average, less than $18 \%$ of 297 Habitats Directive-listed species occurrences within the existing Natura 2000 (see Fig. 2, Data

298 S2). The limited coverage of most species indicates that prioritization at a national level is 299 insufficient to ensure that the favorable conservation status is maintained for most species listed in Habitats Directive. Most species that would not be represented in strictly protected areas are plants; 46 plant species will be strictly protected in areas of less than $10 \mathrm{~km}^{2}$, which may be sufficient only for some range-restricted species since efficient management requires specific measures such as fencing or manual mowing (Heywood 2019). National-level prioritization will also lead to a lack of representation of endangered mammals, such as the European mink Mustela lutreola and the marbled polecat Vormela peregusna. Under the national level prioritization, most of Natura 2000 sites are located within the Continental biogeographic region (51\% of priority areas and $48 \%$ of the region). The Alpine biogeographic region, which harbors most of the remaining old-growth forests in the Carpathian Mountains (Veen et al. 2010), had a relatively low contribution to high-value priority areas (27\% of Alpine region) (see Data S1). The Continental region, which in this scenario would constitute the backbone of strictly protected areas, include many common species when compared to other biogeographic regions (Gruber et al. 2012; Rozylowicz et al. 2019); thus, rare species inhabiting Alpine, Steppic and the Black Sea regions would not be represented in strictly protected areas without a significant expansion of protected areas network. This finding corroborates previous work that found that more than 50\% of sites from Alpine, Steppic, and the Black Sea regions are important for the cohesion of the Natura 2000 network at the national level (Rozylowicz et al. 2019). 
317 The limited contribution of the national-level prioritization scenario may be due to the

318 prioritization algorithm selected for this analysis (Additive Benefit Function), which favors

319 Natura 2000 sites with high species richness (Di Minin et al. 2014). Using other removal rules,

320 such as Core-Area Zonation, which strives to provide the best representation for each individual

321 species, would result in better representation of range-restricted species; as a result, Natura 2000

322 sites with a high number of endemic species would be retained as areas of high biodiversity

323 value (Kukkala et al. 2016); however, forests and other important carbon-rich ecosystems would

324 be missed, thus limiting more their contribution to achieve the EU Biodiversity Strategy for 2030

325 of one-third under strict protection objective.

326 Spatial conservation prioritization relies on the quality of species distribution data (Wiersma and

327 Sleep, 2016). Studies typically opt to limit planning exercises to the best available species data

328 set (e.g., Kukkala et al. 2016; D'Amen M et al. 2013); however, drawing conclusions on data-

329 rich taxa likely limits the application of systematic conservation planning at a continental level

330 that consider species across all taxonomic groups (see Jung et. 2020 for a comprehensive global

331 analysis). Our analysis, while coarse, does explore several taxonomic groups (amphibians,

332 reptiles, fish, mammals, invertebrates, plants), thus providing a national-level perspective on

333 protecting many levels of biodiversity. For example, we found a limited value of applying

334 spatial conservation prioritization algorithms at national level by taxonomic group (see Fig. 3,

335 Fig. S2, Data S2). In our taxa specific scenarios, the top 33\% priority areas overlap 295 Natura

3362000 sites, of which 222 sites include priority areas for invertebrates, 92 sites for amphibians, 73

337 sites for plants, 63 sites for fish species, 58 sites for reptiles, and 42 sites for mammals.

338 Achieving the EU Biodiversity Strategy 203 targets will result in overshooting the one-third

339 strictly protected target, and will require significant land availability and funding to implement,

340 neither being a feasible and efficient prerequisite to conservation in Romania and the EU

341 (Hermoso et al. 2019). Despite their limited value for the EU biodiversity targets, the taxonomic

342 group-based scenarios can be used to identify key areas for a specific taxon and could be used to

343 complement the more realistic, biogeographic regional-based scenarios. This type of

344 prioritization can also be used to understand the data gaps across taxonomic groups. For

345 example, in our case, the top 33\% planning units for 53 invertebrate species include 222 Natura

3462000 sites out of 371 , while for 46 plant species, the prioritization algorithm will select planning

347 units for 73 Natura 2000 sites. The large number of sites selected in the top 33\% for invertebrates 
348 is a direct result of insufficient monitoring efforts for these species, and a lack of taxonomists

349 (Brodie et al. 2019; Cardoso et al. 2011; D'Amen et al. 2013). Data gaps likely resulted in a

350 lower than expected species per site, thus affecting the outcomes of our prioritization exercise.

351 The biogeographical region level prioritization resulted in a balanced distribution of top-priority

352 planning units across the country. This is an expected result, as prioritization using biologically-

353 significant administrative borders will reduce the lower coverage of areas with many range-

354 restricted species (Kukkala et al. 2016). The biogeographic region level planning scenarios also

355 resulted in a smaller number of sites with planning units in top 33\%, with 104 Natura 2000 sites

356 when planning region by region (19 sites belong to more than a region) compared to 222 sites

357 under the national level scenario (see Fig. 4, Data S2). Most sites with top-priority grid cells

358 occur in the Continental region (56 sites) and the Alpine region ( 38 sites), followed by the

359 Steppic and terrestrial Black Sea (23 sites), and the Pannonian regions (8 sites). Biogeographic-

360 focused planning scenarios also performs better in terms of species representation, with only 12

361 species not covered by top-priority planning units (see Data S3, Fig. 5). Only one species is

362 missed by all biogeographic regions - European bison, Bison bonasus) - which would require

363 only one new Natura 2000 site for complete representation (e.g., Tarcu Mountains in SW

364 Romania is on of them, and there are ongoing efforts to reintroduce bison in the Southern

365 Carpathians, Fagaras Mountains).

366 Our prioritization is constrained by the limited availability of occurrence data for most of the

367 Annex II Habitats Directive species. With few exceptions, such as reptiles, amphibians,

368 mammals in the Dobrogea region, large carnivores (Bîrsan et al. 2017; Cogălniceanu et al.

369 2013a; Cogălniceanu et al. 2013b; Cristescu et al. 2019; Miu et al. 2018) species distribution data

370 are available as extent of occurrence, rather than specific locations or modeled species

371 distributions (EIONET 2020). Also, other sources extensively used in prioritization research,

372 such as GBIF (e.g., Guo et al. 2020), include low numbers of occurrence data for Romania. To

373 overcome this shortcoming we used Natura 2000 Standard Data Form, the technical

374 documentation of a Natura 2000 which includes species for which it was designated (Lisón et al.

375 2017), and the spatial resolution of data reported by the Romanian authorities for

376 biogeographical assessments of the conservation status of species and habitats under Article 17

377 of the Habitats Directive (EIONET 2020). While this is less than ideal for systematic

378 conservation planning, it showcases the real-world decision-making process in Eastern European 
379 conservation. This is why we support the existing calls for obtaining robust species distribution

380 data prior to establishing and planning strictly protected areas, especially for overlooked species

381 such as invertebrates (Cardoso et al. 2011).

\section{Conclusions}

383 The EU Biodiversity Strategy for 2030 requires an expansion of protected areas network in

384 Europe, of which one third should be under strict protection as areas of very high biodiversity

385 and climate value. The strategy outlines key principles for designation of strictly protected areas

386 but without providing clear guidelines. To support policymakers in establishing criteria and

387 guidance for meeting the target of one-third of protected areas under strict protection, we provide

388 here a reproducible spatial prioritization case study using Romania's current terrestrial Natura

3892000 network and coarse-scale terrestrial species occurrence. Our results indicate that

390 designation of strictly protected areas using a systematic conservation planning approach at

391 biogeographic region-level would result not only in a good representation of all species protected

392 by EU legislation in a country but also in spatial evenness of selected sites. The species-specific

393 approach used in our example may be easily expanded to include other dimensions of

394 biodiversity, such as carbon-rich areas and old-growth forests, ecological corridors, etc.

395 However, because the results are dependent no only on setting clear targets but also on data

396 quality, we urge policymakers to invest in producing high-quality biodiversity data before

397 proceeding to the designation of new areas of strict protection.

398

399

400

401

402

403

404

405

406

407

\section{Acknowledgments}

We thank the two reviewers for comments and suggestions and Edward F. Rozylowicz for proofreading and suggestions, which helped us to improve the quality of the manuscript.

\section{References}

Apostolopoulou E, and Pantis JD. 2009. Conceptual gaps in the national strategy for the implementation of the European Natura 2000 conservation policy in Greece. Biological Conservation 142:221-237. 10.1016/j.biocon.2008.10.021

Araújo MB, Alagador D, Cabeza M, Nogués-Bravo D, and Thuiller W. 2011. Climate change threatens European conservation areas. Ecology Letters 14:484-492. 10.1111/j.14610248.2011.01610.x

Peer) reviewing PDF | (2020:07:50854:1:0:NEW 26 Aug 2020) 
408 Arponen A, Heikkinen RK, Thomas CD, and Moilanen A. 2005. The value of biodiversity in

409

410

411

412

413

414

415

416

417

418

419

420

421

422

423

424

425

426

427

428

429

430

431

432

433

434

435

436

437 reserve selection: Representation, species weighting, and benefit functions. Conservation Biology 19:2009-2014. 10.1111/j.1523-1739.2005.00218.x

Bîrsan C, Iosif R, Szekely P, and Cogălniceanu D. 2017. Spatio-temporal Bias in the Perceived Distribution of the European Pond Turtle, Emys orbicularis (Linnaeus, 1758), in Romania. Acta Zoologica Bulgarica 10:37-41.

Brodie BS, Popescu VD, Iosif R, Ciocanea C, Manolache S, Vanau G, Gavrilidis AA, Serafim R, and Rozylowicz L. 2019. Non-lethal monitoring of longicorn beetle communities using generic pheromone lures and occupancy models. Ecological Indicators 101:330-340. 10.1016/j.ecolind.2019.01.038

Cardoso P, Erwin TL, Borges PA, and New TR. 2011. The seven impediments in invertebrate conservation and how to overcome them. Biological Conservation 144:2647-2655 DOI: 10.1016/j.biocon.2011.07.024

Cogălniceanu D, Rozylowicz L, Székely P, Samoilă C, Stănescu F, Tudor M, Székely D, and Iosif R. 2013a. Diversity and distribution of reptiles in Romania. ZooKeys 341:49-76 DOI: $10.3897 /$ zookeys.341.5502

Cogălniceanu D, Székely P, Samoilă C, Iosif R, Tudor M, Plăiaşu R, Stănescu F, and Rozylowicz L. 2013b. Diversity and distribution of amphibians in Romania. ZooKeys 296:35-57 DOI: 10.3897/zookeys.296.4872

Council Directive 92/43/EEC. Council Directive 92/43/EEC of 21 May 1992 on the conservation of natural habitats and of wild fauna and flora. Available at https://eurlex.europa.eu/legal-content/EN/TXT/?uri=celex:31992L0043 (accessed 24 August 2020).

Cristescu B, Domokos C, Teichman KJ, and Nielsen SE. 2019. Large carnivore habitat suitability modelling for Romania and associated predictions for protected areas. PeerJ 7:e6549 DOI: 10.7717/peerj.6549

D'Amen M, Bombi P, Campanaro A, Zapponi L, Bologna MA, and Mason F. 2013. Protected areas and insect conservation: Questioning the effectiveness of Natura 2000 network for saproxylic beetles in italy. Animal Conservation 16:370-378 DOI: 10.1111/acv.12016

DG Environment. 2020. Natura 2000 barometer. Natura 2000 Nature and biodiversity newsletter $47: 8-9$. 
438 Di Minin E, Veach V, Lehtomäki J, Pouzols FP and Moilanen A. 2014. A quick introduction to 439 Zonation. Version 1 (for Zv4). University of Helsinki

440

441

442

443

444

445

446

447

448

449

450

451

452

453

454

455

456

457

458

459

460

461

462

463

464

465

466

467

468

Dimitrakopoulos PG, Memtsas D, and Troumbis AY. 2004. Questioning the effectiveness of the Natura 2000 Special Areas of Conservation strategy: The case of Crete. Global Ecology and Biogeography 13:199-207 DOI: 10.1111/j.1466-822X.2004.00086.x

Directive 2009/147/EC. Directive 2009/147/EC of the European Parliament and of the Council of 30 November 2009 on the conservation of wild birds. Available at https://eurlex.europa.eu/legal-content/EN/TXT/?uri=CELEX:02009L0147-20190626 (accessed 24 August 2020)

EIONET. 2020. Central Data Repository. Natura 2000 network (Birds Directive and Habitats Directive). $\quad$ Natura 2000 updating 2019. Available at https://cdr.eionet.europa.eu/ro/eu/n2000/envxdvb_a/(accessed March, 5 2020).

European Commission. 2020. EU Biodiversity Strategy for 2030. Bringing nature back into our lives. Communication from the Commission to the European Parliament, the Council, the European Economic and Social Committee and the Committee of the Regions. Available at https://eur-lex.europa.eu/legal-content/EN/TXT/?uri=CELEX:52020DC0380 (accessed 24 August 2020).

Evans D. 2012. Building the European Union's Natura 2000 network. Nature conservation 1:11 DOI: $10.3897 /$ natureconservation. 1.1808

Geldmann J, Barnes M, Coad L, Craigie ID, Hockings M, and Burgess ND. 2013. Effectiveness of terrestrial protected areas in reducing habitat loss and population declines. Biological Conservation 161:230-238 DOI: 10.1016/j.biocon.2013.02.018

Gray CL, Hill SLL, Newbold T, Hudson LN, Börger L, Contu S, Hoskins AJ, Ferrier S, Purvis A, and Scharlemann JPW. 2016. Local biodiversity is higher inside than outside terrestrial protected areas worldwide. Nature Communications 7:12306 DOI: $10.1038 /$ ncomms 12306

Gruber B, Evans D, Henle K, Bauch B, Schmeller D, Dziock F, Henry P-Y, Lengyel S, Margules C, and Dormann C. 2012. "Mind the gap!"-How well does Natura 2000 cover species of European interest? Nature conservation 3:45 DOI: 10.3897/natureconservation.3.3732

Guo W-Y, Serra-Diaz JM, Schrodt F, Eiserhardt WL, Maitner BS, Merow C, Violle C, Anand M, Belluau M, Bruun HH, Byun C, Catford JA, Cerabolini BEL, Chacón-Madrigal E, 
469

470

471

472

473

474

475

476

477

478

479

480

481

482

483

484

485

486

487

488

489

490

491

492

493

494

495

496

Ciccarelli D, Cornelissen JHC, Dang-Le AT, de Frutos A, Dias AS, Giroldo AB, Guo K, Gutiérrez AG, Hattingh W, He T, Hietz P, Hough-Snee N, Jansen S, Kattge J, Klein T, Komac B, Kraft N, Kramer K, Lavorel S, Lusk CH, Martin AR, Mencuccini M, Michaletz ST, Minden V, Mori AS, Niinemets Ü, Onoda Y, Onstein RE, Peñuelas J, Pillar VD, Pisek J, Robroek BJM, Schamp B, Slot M, Sosinski Ê, Soudzilovskaia NA, Thiffault N, van Bodegom P, van der Plas F, Wright IJ, Xu W-B, Zheng J, Enquist BJ, Svenning J-C. 2020. Half of the world's tree biodiversity is unprotected and is increasingly threatened by human activities. bioRxiv DOI: 10.1101/2020.04.21.052464.

Hermoso V, Clavero M, Villero D, and Brotons L. 2017. EU's Conservation Efforts Need More Strategic Investment to Meet Continental Commitments. Conservation Letters 10 231237 DOI: $10.1111 /$ conl.12248

Hermoso V, Morán-Ordóñez A, Canessa S, Brotons L. 2019. Realising the potential of Natura 2000 to achieve EU conservation goals as 2020 approaches. Scientific Reports 9. DOI: $10.1038 / \mathrm{s} 41598-019-52625-4$.

Heywood VH. 2019. Conserving plants within and beyond protected areas - still problematic and future uncertain. Plant Diversity 41:36-49. DOI: 10.1016/j.pld.2018.10.001.

Iojă CI, Pătroescu M, Rozylowicz L, Popescu VD, Vergheleţ M, Zotta M, and Felciuc M. 2010. The efficacy of Romania's protected areas network in conserving biodiversity. Biological Conservation 143:2468-2476 DOI: 10.1016/j.biocon.2010.06.013

Jung M, Arnell A, de Lamo X, García-Rangel S, Lewis M, Mark J, Merow C, Miles L, Ondo I, Pironon S, Ravilious C, Rivers M, Schepashenko D, Tallowin O, van Soesbergen A, Govaerts R, Boyle BL, Enquist BJ, Feng X, Gallagher RV, Maitner B, Meiri S, Mulligan M, Ofer G, Hanson JO, Jetz W, Di Marco M, McGowan J, Rinnan DS, Sachs JD, Lesiv M, Adams V, Andrew SC, Burger JR, Hannah L, Marquet PA, McCarthy JK, MoruetaHolme N, Newman EA, Park DS, Roehrdanz PR, Svenning JC, Violle C, Wieringa JJ, Wynne G, Fritz S, Strassburg BBN, Obersteiner M, Kapos V, Burgess N, Schmidt-Traub $\mathrm{G}$ and Visconti P. 2020. Areas of global importance for terrestrial biodiversity, carbon, and water. bioRxiv. DOI: 10.1101/2020.04.16.021444. 
497 Kenig-Witkowska MM. 2017. Natura 2000-The European Union Mechanism for Nature 498 Conservation: Some Legal Issues. Journal of Comparative Urban Law and Policy 2:198499 214.

500

501

502

503

504

505

506

507

508

509

510

511

512

513

514

515

516

517

518

519

520

521

522

523

524

525

526

Kukkala AS, Arponen A, Maiorano L, Moilanen A, Thuiller W, Toivonen T, Zupan L, Brotons L, and Cabeza M. 2016. Matches and mismatches between national and EU-wide priorities: Examining the Natura 2000 network in vertebrate species conservation. Biological Conservation 198:193-201 DOI: 10.1016/j.biocon.2016.04.016

Lehtomäki J, and Moilanen A. 2013. Methods and workflow for spatial conservation prioritization using Zonation. Environmental Modelling and Software 47:128-137 DOI: 10.1016/j.envsoft.2013.05.001

Lisón F, Altamirano A, Field R, and Jones G. 2017. Conservation on the blink: Deficient technical reports threaten conservation in the Natura 2000 network. Biological Conservation 209:11-16 DOI: 10.1016/j.biocon.2017.02.003

Lisón F, Palazón JA, and Calvo JF. 2013. Effectiveness of the Natura 2000 Network for the conservation of cave-dwelling bats in a Mediterranean region. Animal Conservation 16:528-537 DOI: $10.1111 / \mathrm{acv} .12025$

Manolache S, Ciocanea CM, Rozylowicz L, and Nita A. 2017. Natura 2000 in Romania-a decade of governance challenges. European Journal of Geography 8:24-34.

Mânzu C, Gherghel I, Zamfirescu Ş, Zamfirescu O, Roşca I, and Strugariu A. 2013. Current and future potential distribution of glacial relict Ligularia sibirica (Asteraceae) in Romania and temporal contribution of Natura 2000 to protect the species in light of global change. Carpathian Journal of Earth and Environmental Sciences 8:77-87.

Margules CR, and Pressey RL. 2000. Systematic conservation planning. Nature 405:243-253 DOI: $10.1038 / 35012251$

Mikkonen N, and Moilanen A. 2013. Identification of top priority areas and management landscapes from a national Natura 2000 network. Environmental science \& policy 27:1120 DOI: $10.1016 /$ j.envsci.2012.10.022

Miu IV, Chisamera GB, Popescu VD, Iosif R, Nita A, Manolache S, Gavril VD, Cobzaru I, and Rozylowicz L. 2018. Conservation priorities for terrestrial mammals in Dobrogea Region, Romania. ZooKeys 158:133-158 DOI: 10.3897/zookeys.792.25314 
527 Moilanen A, Franco AMA, Early RI, Fox R, Wintle B, and Thomas CD. 2005. Prioritizing 528 multiple-use landscapes for conservation : methods for large multi-species planning 529 problems. 57:1885-1891 DOI: 10.1098/rspb.2005.3164

530 Moilanen A, Leathwick JR, and Quinn JM. 2011. Spatial prioritization of conservation 531 management. Conservation Letters 4:383-393 DOI: 10.1111/j.1755-263X.2011.00190.x

532 Moilanen A, Pouzols FM, Meller L, Veach V, Arponen A, Leppänen J, and Kujala H. 2014. 533 Spatial conservation planning methods and software ZONATION. User Manual. 534 DOI:10.1017/CBO9781107415324.004

535 Moilanen A. 2007. Landscape Zonation, benefit functions and target-based planning: Unifying 536 reserve selection strategies. Biological Conservation 134:571-579 DOI: 537 10.1016/j.biocon.2006.09.008

538 Müller A, Schneider UA, and Jantke K. 2018. Is large good enough? Evaluating and improving 539 representation of ecoregions and habitat types in the European Union's protected area network Natura 2000. Biological Conservation 227:292-300 DOI: 10.1016/j.biocon.2018.09.024

Müller A, Schneider UA, and Jantke K. 2020. Evaluating and expanding the European Union's protected-area network toward potential post-2020 coverage targets. Conservation Biology 34:654-665 DOI: 10.1111/cobi.13479

545 Nita A, Rozylowicz L, Manolache S, Ciocănea MC, Miu VI, and Popescu DV. 2016. Collaboration Networks in Applied Conservation Projects across Europe. Plos One 11: e0164503:1-16 DOI: 10.1371/journal.pone.0164503

Orlikowska EH, Roberge JM, Blicharska M, and Mikusiński G. 2016. Gaps in ecological research on the world's largest internationally coordinated network of protected areas: A review of Natura 2000. Biological Conservation 200:216-227 DOI: 10.1016/j.biocon.2016.06.015

553

554

Popescu VD, Rozylowicz L, Cogălniceanu D, Niculae IM, and Cucu AL. 2013. Moving into Protected Areas? Setting Conservation Priorities for Romanian Reptiles and Amphibians at Risk from Climate Change. PLoS ONE 8:e79330. DOI: 10.1371/journal.pone.0079330

Possingham HP, Wilson KA, Andelman SJ, and Vynme CH. 2006. Protected Areas: Goals, Limitations, and Design. In: Groom MJ, Meffe GK, Carroll RC ed. Principles of Conservation Biology. Boston: Sinauer Associates, 509-533. 
558 Pressey RL, Cabeza M, Watts ME, Cowling RM, and Wilson KA. 2007. Conservation planning 559 in a changing world. Trends in ecology \& evolution 22:583-592. DOI:

560

561 562

563

564

565

566

567

568

569

570

571

572

573

574

575

576

577

578

579

580

581 10.1016/j.tree.2007.10.001

Rey V, Ianos I, Groza O, and Patroescu M. 2007. Atlas de la Roumanie. Nouvelle edition. Montpellier: Reclus.

Rodrigues ASL, Andelman SJ, Bakarr MI, Boitani L, Brooks TM, Cowling RM, Fishpool LDC, Da Fonseca GAB, Gaston KJ, Hoffmann M, Long JS, Marquet PA, Pilgrim JD, Pressey RL, Schipper J, Sechrest W, Stuart SN, Underhill LG, Waller RW, Watts MEJ, and Yan X. 2004. Effectiveness of the global protected area network in representing species diversity. Nature 428:640-643. DOI: 10.1038/nature02422

Rozylowicz L, Nita A, Manolache S, Popescu VD, and Hartel T. 2019. Navigating protected areas networks for improving diffusion of conservation practices. Journal of Environmental Management 230:413-421. DOI: 10.1016/j.jenvman.2018.09.088

UNEP. 2011. Strategic Plan for Biodiversity 2011-2020: Further Information Related to the Technical Rationale for the Aichi Biodiversity Targets, Including Potential Indicators and Milestones. New York: UNEP.

Veen P, Fanta J, Raev I, Biriş I-A, de Smidt J, Maes B. 2010. Virgin forests in Romania and Bulgaria: results of two national inventory projects and their implications for protection. Biodiversity and Conservation 19:1805-1819. DOI: 10.1007/s10531-010-9804-2.

Votsi NEP, Zomeni MS, and Pantis JD. 2016. Evaluating the Effectiveness of Natura 2000 Network for Wolf Conservation: A Case-Study in Greece. Environmental Management 57:257-270. DOI: 10.1007/s00267-015-0621-y

Wiersma YF, Sleep DJH. 2016. A review of applications of the six-step method of systematic conservation planning. The Forestry Chronicle 92:322-335. DOI: 10.5558/tfc2016-059. 


\section{Table $\mathbf{1}$ (on next page)}

Representation of protected species by Natura 2000 sites with grid cells selected as high priority in national level prioritization scenario (gap and most represented species). 
1

\begin{tabular}{|c|c|c|}
\hline $\begin{array}{l}\text { Taxonomic } \\
\text { group }\end{array}$ & Species & $\begin{array}{l}\text { Number of top } 33 \% \\
\text { Natura } 2000 \text { sites } \\
\text { covering the species }\end{array}$ \\
\hline \multirow[t]{2}{*}{ Plants } & $\begin{array}{l}\text { Centaurea jankae, Potentilla emilii-popii, } \\
\text { Centaurea pontica, Dracocephalum austriacum, } \\
\text { Ferula sadleriana, Gladiolus palustris, Stipa } \\
\text { danubialis, Thlaspi jankae, Tulipa hungarica, } \\
\text { Paeonia officinalis subsp. banatica, Colchicum } \\
\text { arenarium, Saxifraga hirculus }\end{array}$ & 0 \\
\hline & Ligularia sibirica & 17 \\
\hline \multirow[t]{2}{*}{ Invertebrates } & $\begin{array}{l}\text { Graphoderus bilineatus, Stenobothrus eurasius, } \\
\text { Isophya harzi, Vertigo moulinsiana }\end{array}$ & 0 \\
\hline & Lucanus cervus & 41 \\
\hline \multirow{2}{*}{ Fish } & Cobitis elongata, Rutilus pigus & 0 \\
\hline & Barbus meridionalis & 62 \\
\hline \multirow{2}{*}{ Amphibians } & - & 0 \\
\hline & Bombina variegata & 108 \\
\hline \multirow{2}{*}{ Reptiles } & - & 0 \\
\hline & Emys orbicularis & 24 \\
\hline \multirow{2}{*}{ Mammals } & Mustela lutreola, Rhinolophus mehelyi & 0 \\
\hline & Lutra lutra & 110 \\
\hline
\end{tabular}

2 
Figure 1

\section{Flowchart illustrating the spatial prioritization process (national, taxa-specific and biogeographical levels spatial prioritization scenarios).}
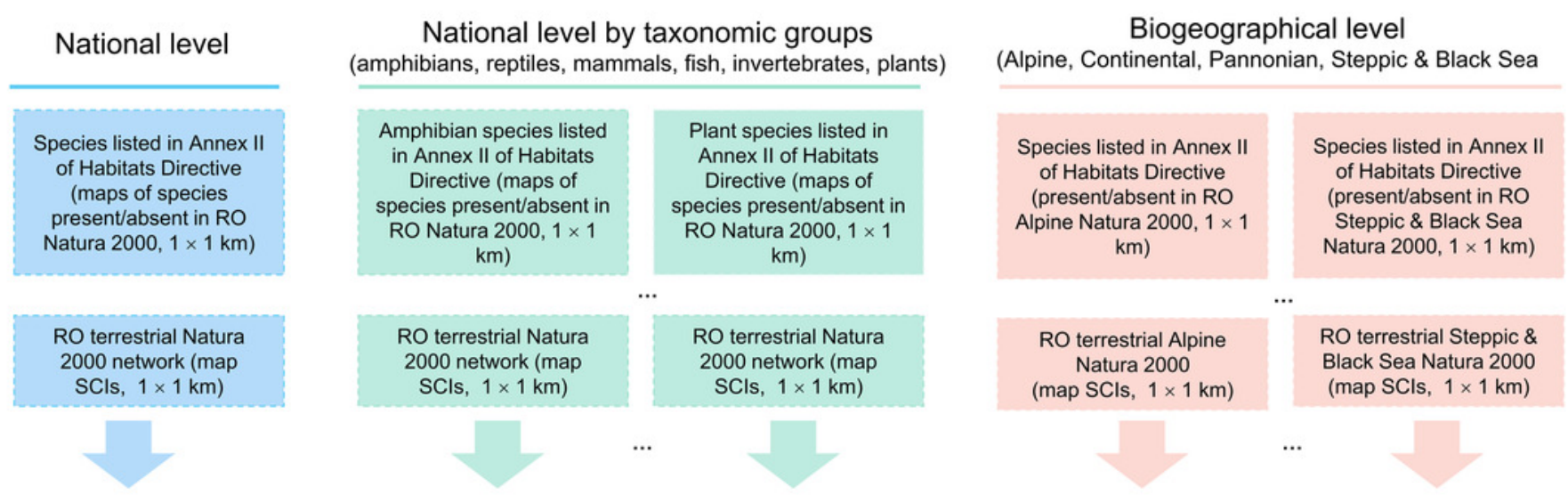

Prioritization analyses: Zonation v4 with Additive Benefit Function as grid cell removal rule
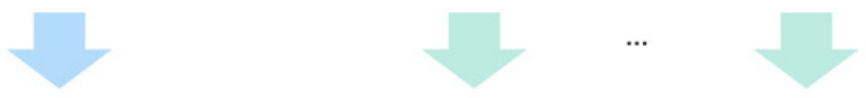

Outputs: Ranking of planning units within existing Romanian terrestrial Natura 2000; scenario performance curves; number of species protected by Romanian terrestrial Natura 2000 sites with planning units in top $33 \%$

Recommended scenario for selection of areas of very high biodiversity value within the Romanian terrestrial Natura 2000 network 
Figure 2

High priority sites for designation as areas under strict protection (national level prioritization scenario).

Grid cells within the Romanian terrestrial Natura 2000 network have been graded according to their priority, with the highest-priority sites (top 33\%) shown in red. Biogeographic regions are numbered as follows: I (Alpine), II (Continental), III (Pannonian), IV (Steppic and terrestrial Black Sea).

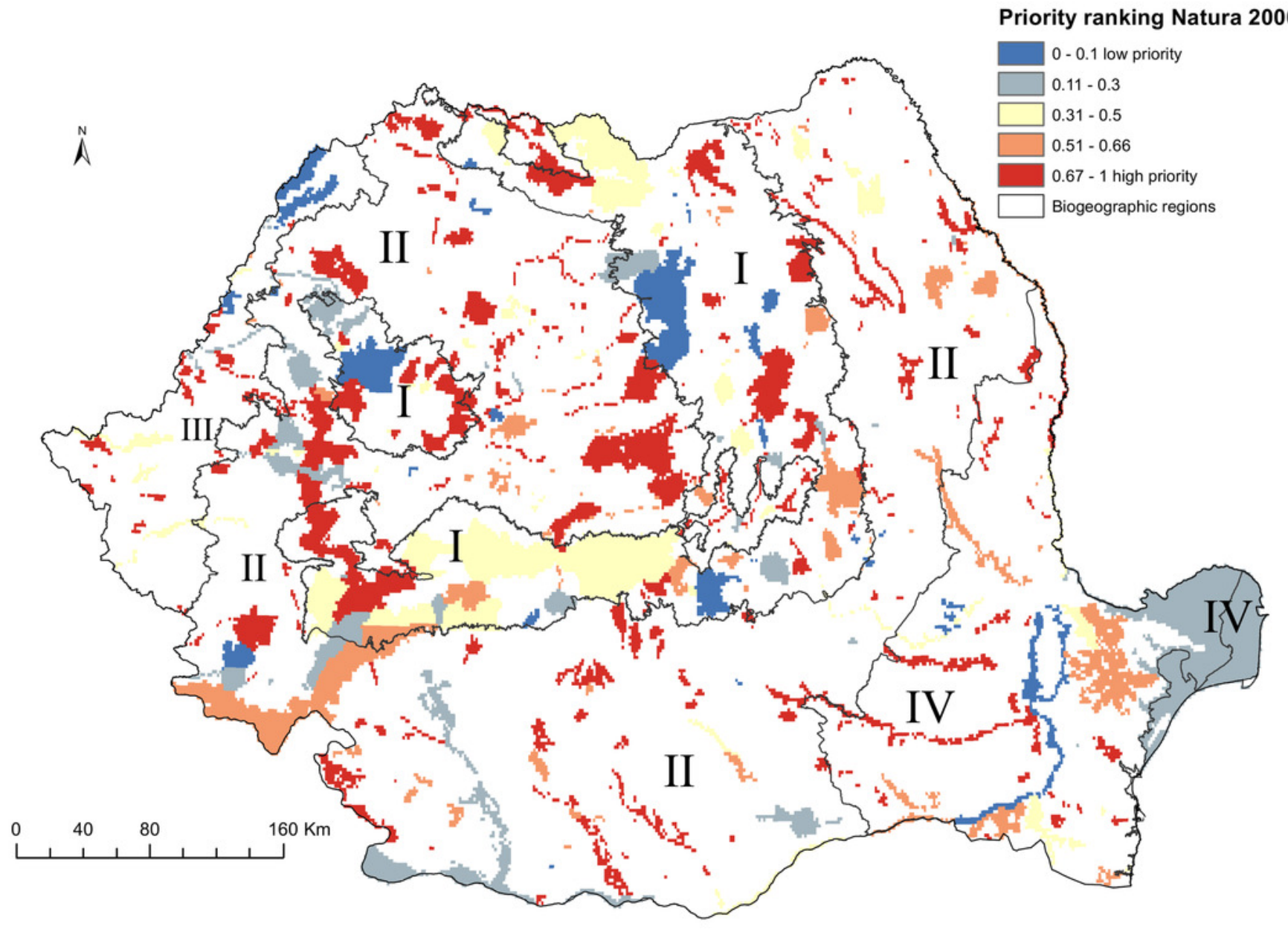




\section{Figure 3}

High priority sites for designation as areas under strict protection (taxonomic level prioritization scenario).

Grid cells within the Romanian terrestrial Natura 2000 network have been graded according to their priority, with the highest-priority sites (top 33\%) shown in red. Biogeographic regions are numbered as follows: I (Alpine), II (Continental), III (Pannonian), IV (Steppic and terrestrial Black Sea). (A) Amphibians. (B) Reptiles. (C) Invertebrates. (D) Fish. (E) Mammals. (F) Plants. 

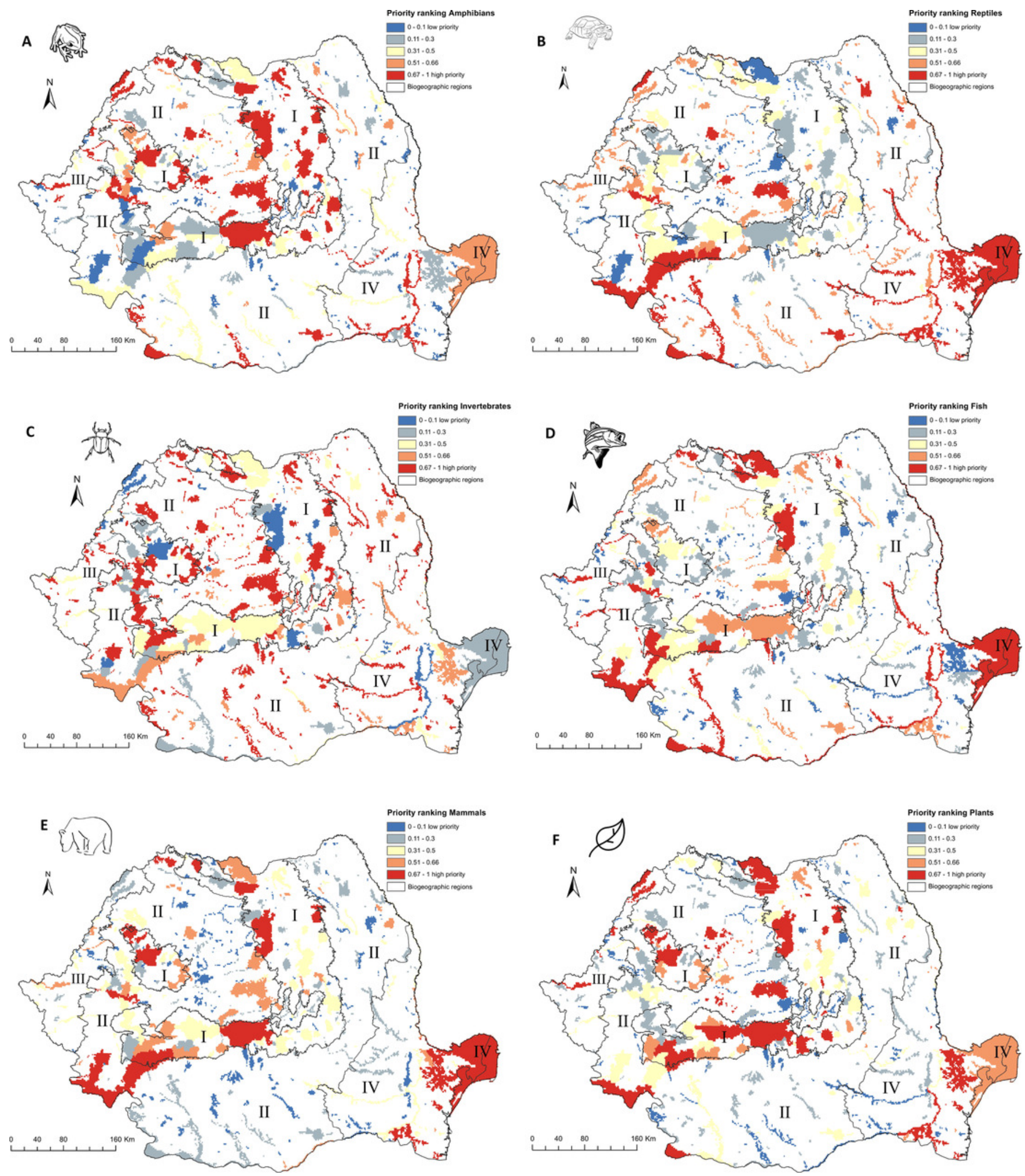


\section{Figure 4}

High priority sites for designation as areas under strict protection (biogeographical level prioritization scenario).

Grid cells within the Romanian terrestrial Natura 2000 network have been graded according to their priority, with the highest-priority sites (top 33\%) shown in red. (A) Alpine biogeographic region. (B) Continental biogeographic region. (C) Pannonian biogeographic region. (D) Steppic and terrestrial Black Sea biogeographic region.
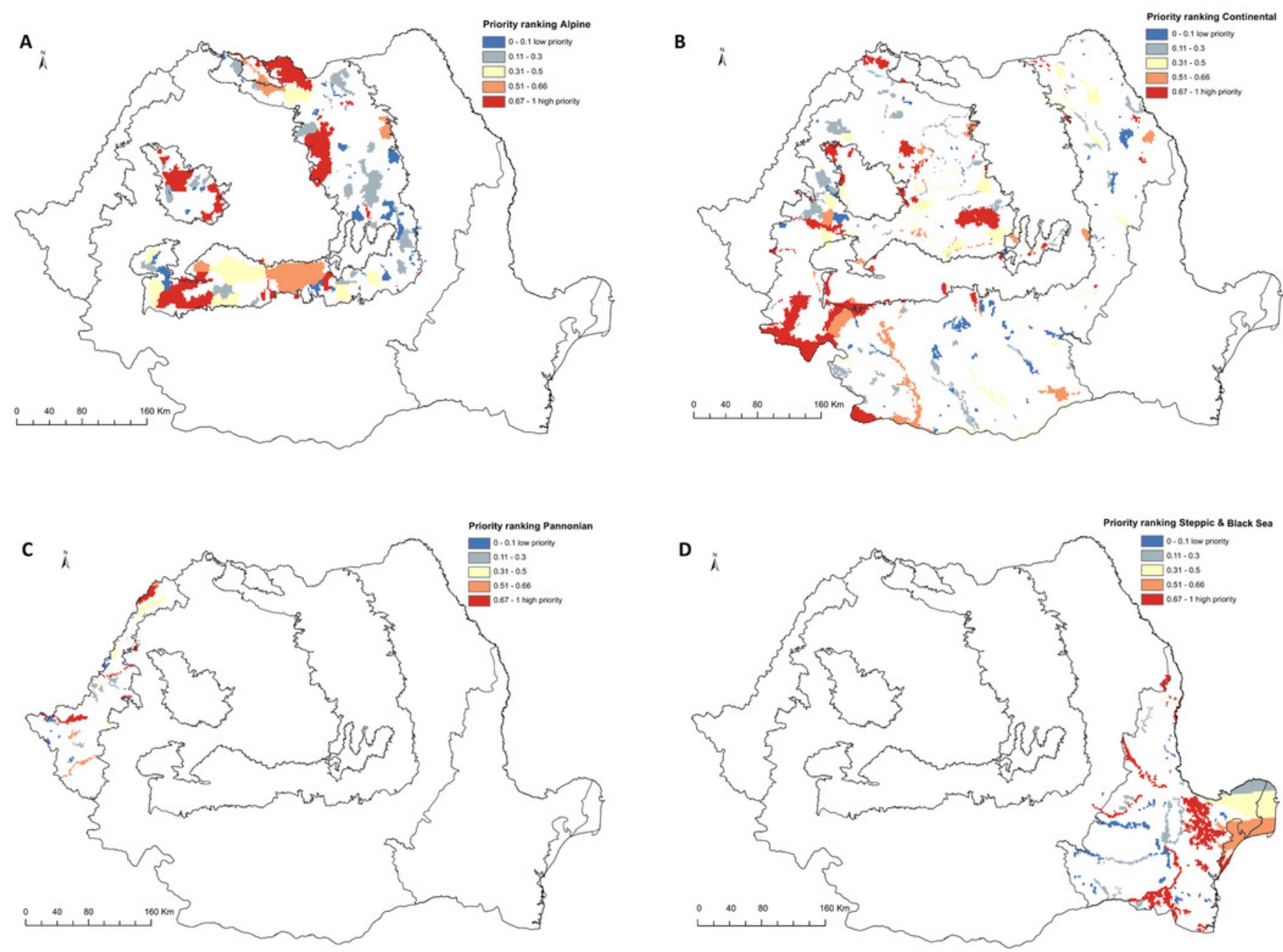


\section{Figure 5}

Species representation in the top 33\% planning units by prioritization scenarios.

Red $=$ gap species (never included in Natura 2000 sites with high priority grid cells in the respective scenario), Blue $=$ covered species (included in Natura 2000 sites with high priority grid cells in the respective scenario). $R O=$ national level scenario. $A L P R O=$ Alpine EBR in national level scenario. $A L P B R=$ Alpine EBR in biogeographical level scenario; $C O N$ RO = Continental EBR in national level scenario. CON BR $=$ Continental EBR in biogeographical level scenario; PAN RO = Pannonian EBR in national level scenario. PAN BR = Pannonian EBR in biogeographical level scenario; STE RO = Steppic and terrestrial Black Sea EBR in national level scenario. STE BR = Steppic and terrestrial Black Sea EBR in biogeographical level scenario.
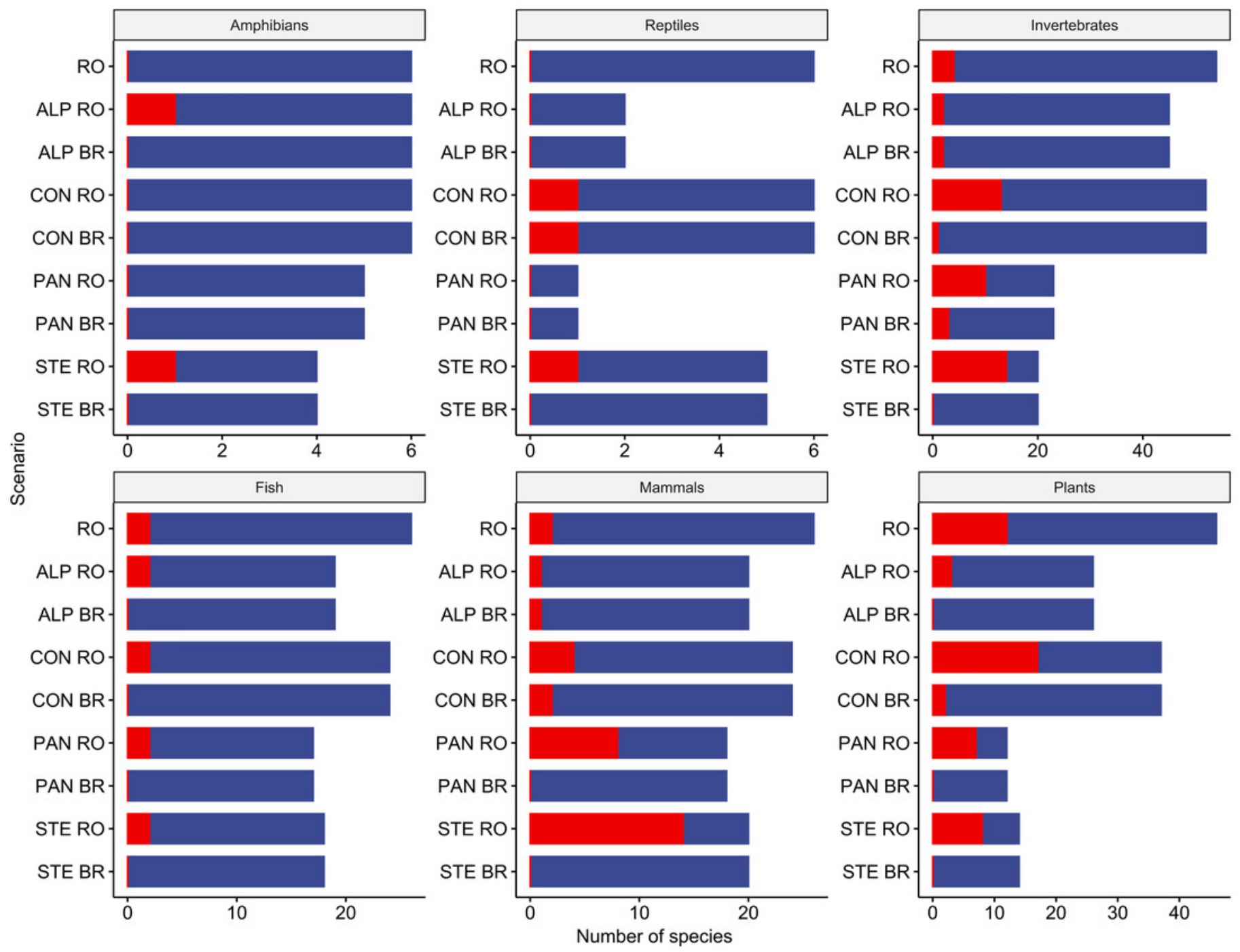